\title{
Risk of local extinction and genetic diversity of Melipona quadrifasciata (Apidae: Meliponini) in a possible Northeastern limit of its distribution in Brazil
}

\author{
ED Araujo ${ }^{1}$, RG Oliveira ${ }^{1}$, HCM Calazans ${ }^{1}$, CCS França ${ }^{1}$, V Santos ${ }^{1}$, GT Ribeiro ${ }^{1}$, S Jain ${ }^{1}$, MVA Batista ${ }^{1}$, LA Nunes $^{2}$ \\ 1 - Federal University of Sergipe, São Cristóvão-SE, Brazil \\ 2 - State University of Southwestern Bahia, Jequie-BA, Brazil
}

\section{Article History}

\section{Edited by}

Cândida M. L. Aguiar, UEFS, Brazil

Received $\quad 09$ November 2015

Initial acceptance 17 December 2015

Final acceptance 20 April 2016

Publication date 15 July 2016

\section{Keywords}

Coconut trees, nesting site, geometric morphometrics, stingless bee, molecular marker.

\section{Corresponding author}

Edilson Divino de Araujo

Federal University of Sergipe

São Cristóvão-SE, Brazil

E-Mail: edaraujo@ufs.br

\begin{abstract}
Rapid loss of genetic diversity among eusocial bees, and extinction of their local population has become a major world concern. Populations of $M$. quadrifasciata have increasingly declined due to predatory extractivism and destruction of their habitat. Knowledge of their local population could give insights on the strategies for monitoring and conservation of this species. In this study, initially, 14 colonies from the northern limit of the northeastern sandbank of the Atlantic Forest were analysed employing geometric morphometrics techniques. Then the cytochrome $b$ gene sequences and ISSR primers were utilized for molecular analysis of these colonies and the results were compared with $15 \mathrm{M}$. quadrifasciata colonies found in the semiarid Caatinga region. The morphometrics and the molecular analysis suggested the formation of disjunct populations between the studied geographical zones. All the 14 colonies analysed from the São Francisco river region were found on the Southern margin of the São Francisco river and they all belonged to one single haplotype. No colonies were found on the Northern bank of the river. We suggest that the São Francisco river is an effective geographical barrier for the distribution of this species and propose an urgent need for the development of a conservation program for the population of $M$. quadrifasciata as it represents a unique haplotype in the region. Also their nesting habit exclusively in the diseased coconut trees which probably will be replaced by new trees, create the risk of population extinction due to the lack of nesting site.
\end{abstract}

\section{Introduction}

The stingless bees have an important ecological role, especially in the pollination of a large fraction of plants forming Brazilian forests. The stingless bee M. quadrifasciata is considered a generalist species, acting as a pollinator of several plant species and playing an important ecological role in the ecosystem (Ramalho et al., 2004; Antonini et al., 2006).

In Melipona genus, the bee M. quadrifasciata is one of the best known species found in Brazil and is divided into two subspecies M. quadrifasciata quadrifasciata (Lepeletier) and M. quadrifasciata anthidioides (Lepeletier) (Waldschmidt et al., 2002). M. quadrifasciata quadrifasciata was initially registered in colder biomes located in Rio Grande do Sul and Southeast Brazil, with patterns of yellow continuous tergal bands, and M. quadrifasciata anthidioides is found in Northeastern São Paulo along the East coast of Brazil until the state of Paraíba with patterns of interrupted tergal bands. There is a zone of hybridization of this species in the Southeastern Brazil between the states of São Paulo and Minas Gerais (Silveira et al., 2002; Camargo \& Pedro, 2007; Tavares et al., 2013).

Waldschmidtet al. (2000) reported that individuals with a pattern similar to the continuous tergal bands of $M$. quadrifasciata quadrifasciata can be found in warm climates. This fact was confirmed by Batalha-Filho et al. (2009) who found 
specimens with standard tergal bands of $M$. quadrifasciata quadrifasciata in the semiarid region in the states of Bahia and Sergipe, in the Northeast of Brazil. These authors concluded that existence of more than two groups should be considered within this subspecies according to their phylogeographical pattern, and suggest that the level of genetic variation is too low for their division into different subspecies.

According to Kerr et al. (1996), the changes caused by anthropogenic disturbances have promoted changes in habitats, compromising the diversity of stingless bees due to the reduction in nesting sites and the availability of trophic resources, unfavourable for the maintenance of the natural colonies. The reduction of these resources promotes both the local disappearance of certain species, as well as forces nesting in unusual sites (Souza et al.,2009).

The first scientific record of a population of M. quadrifasciata, using hollow coconut trunk (Cocus nucifera L.) as nesting site, at the mouth of the river São Francisco in the state of Sergipe was made in by Souza et al. (2006). These authors also called attention to the conflict between shortage of nesting sites in the region, habitat fragmentation and the dependence of this species on nesting sites located in trunks of the economically doomed coconut trees attacked by the weevils.

In the beginning of the colonization of Brazil by the Portuguese, in the sixteenth century, the Atlantic Forest covered practically the entire Brazilian coast. In the same century, in the year of 1587, the first records of the introduction of coconut (Cocus nucifera L.) were described in Brazil. Since then, coconut cultivation has proliferated due to its high suitability to the climate conditions and sandy soils of the Brazilian coast in Atlantic Rainforest Biome (Siqueira et al., 2002). In the late twentieth century, the coconut crop was spread over an area of 247,000 ha with a production of about 1.1 billion fruits, with over $70 \%$ of production concentrated in the Northeastern Brazil (Cuenca \& Nazario, 2004).

The incidence of pests in coconut trees is an important limiting factor accounting significantly for the economic losses of the plantations and reduced productivity. Beetles of the species Rhinostomus barbirostrise (Fabricius, 1775) are among the principal coconut palm borers. Cutting and burning of the heavily infested coconut trees is usually recommend by the area supervisors in order to reduce the spread of the beetle (Araújo et al., 2015).

Ribeiro et al. (2009) in a study on the Brazilian Atlantic forest revealed a serious situation with respect to the forest fragmentation, with more than $80 \%$ of the fragments $<50$ ha and almost half the remaining forest $<100 \mathrm{~m}$ from its edges. They also reported the presence of large average distance $(1440 \mathrm{~m})$ between the fragments, the fact that the São Francisco river region has only $4.7 \%$ of forest cover and that the main land use in this area is associated with plantations of coconut. Extensive forest fragmentation results in the isolation of bee population, compromising the genetic diversity of bees and reduced availability of the trophic resources. This can lead to the loss of natural colonies, and local species extinction (Carvalho et al., 1995). The decrease of forest areas, forming fragments, reduces the size of the populations that live and depend on this habitat. These processes directly affect eusocial bees that use tree hollows for nesting, isolating small populations and leading them to inbreeding, genetic drift and local extinction (Beaumont \& Bruford, 1999; Araújo et al., 2004).

In the case of the stingless bees, genetic drift is an extremely important factor in the isolation of small local populations. Araújo et al. (2000) suggested that the populations of Melipona are particularly sensitive to the effect of genetic drift due to homozygosity in the Xo sex determination locus. Carvalho et al. (1995) documented the loss of alleles and the extinction of local populations due to low population number and Kerr and Vencovsky (1982) described that a Meliponini population should contain a minimum of 44 colonies to lower the risks of rapid extinction.

In addition to the morphological analysis, the use of molecular markers and geometric morphometrics can be used to clarify questions regarding hybridization, dispersal and geographic distribution, genetic identity and risks of extinction (Moritz \& Hills, 1996; Chakraborty \& Kimmel, 1999; Waldschmidt et al., 2002; Araújo et al., 2004; Nascimento et al., 2010).

This study aimed to evaluate the genetic diversity and the risk of local extinction of a population of M. quadrifasciata that uses coconut trunks predominantly as nesting site in an area used for coconut plantation at the mouth of the São Francisco river in the Northeastern Brazil. For this, first geometric morphometric analysis was carried out to identify the river specie found at the mouth of the São Francisco and then molecular analyses were carried out to compare this population with another natural population of $M$. quadrifasciata with the same pattern of continuous tergal bands found in the Caatinga biome which is the closest biome where this species occurs naturally.

\section{Material and Methods}

Samples

Coconut plantation from an area South of the mouth of the São Francisco river (Brejo Grande, state of Sergipe), from the North of the mouth of the river São Francisco river (Piaçabuçu, state of Alagoas), and from an island (Criminosa island) formed by the São Francisco river between the states of Alagoas and Sergipe were visually examined for the presence of bee nests. These three areas of coconut plantations totalled an area of approximately 37 ha (Table 1).

The island had a distinct physiognomy than the other two areas of sandbank. The sandbanks were primarily composed of wetlands characterized as floodplain and used for coconut cultivation in elevated regions, and covered by Aningas (Montrichardia arborescens L.) in the lower regions. The search for nests was conducted randomly, traversing the 
Table 1 - Geographical location of sample areas in the region of the mouth of São Francisco river.

\begin{tabular}{lllll}
\hline Local & Latitude (S) & Longitude (W) & $\begin{array}{l}\text { Number } \\
\text { of plants } \\
\text { observed }\end{array}$ & $\begin{array}{l}\text { Area } \\
\text { (ha) }\end{array}$ \\
\hline Brejo Grande-SE & $10^{\circ} 28^{\prime} 47^{\prime \prime}$ & $36^{\circ} 26^{\prime} 21^{\prime \prime}$ & 200 & 13.5 \\
Criminosa Island & $10^{\circ} 28^{\prime} 47^{\prime \prime}$ & $36^{\circ} 24^{\prime} 68^{\prime \prime}$ & 270 & 9 \\
Piaçabuçu- AL & $10^{\circ} 26^{\prime} 96^{\prime \prime}$ & $36024^{\prime} 81^{\prime \prime}$ & 280 & 14.5 \\
\hline
\end{tabular}

coconut trees and other potential nesting sites along the path, using the same sampling profile (three persons in each area). All the tree trunks were numbered and, when a colony was identified, it was marked and registered, specimens were collected with the help of an entomologist and characteristics of their activity, morphology and height of the nests were recorded. 10 workers per nest were captured. The captured bees were placed in numbered containers, containing $70 \%$ alcohol for preservation of the material.

For molecular analysis, apart from 140 workers from Brejo Grande (S 10 28'47' and W 36 $26^{\prime} 21^{\prime \prime}$ '), 150 workers from the municipality of Nossa Senhora da Glória, Sergipe (semiarid Caatinga region $\mathrm{S} 10^{\circ} 13^{\prime} 06^{\prime \prime}$ and W $37^{\circ} 25^{\prime} 13^{\prime \prime}$ ) were also used. The standard specimens $M$. q. anthidioides, M. $q$. quadrifasciata and M. mandacaia utilized were provided by the Federal University of Reconcavo of Bahia, Cruz das Almas, BA.

\section{Geometric Morphometrics}

The left forewing of all the workers from river São Franciscoregion were mounted on the slides and placed under disecting microscope. Photomicrographs of the forewings were organized in Tps Util software and 13 anatomical landmarks were marked using the TpsDig2 software version 2.10 (Rohlf, 2006), as illustrated in Figure 1.

The anatomical landmarks were then transformed into arrays of coordinates. These coordinates were adjusted using orthogonal superimpositions of least squares criterion using MorphoJ software (Klingenberg, 2010).

After adjusting the size, position and orientation, and generation of an array of covariance, Principal Component Analysis (PCA) was performed. Besides the formation of the groups, the degree of population diversity was observed by the analysis of canonical variables. To identify the difference between the groups for the size and shape of individuals, analysis of variance (ANOVA) of Procrustes was performed.

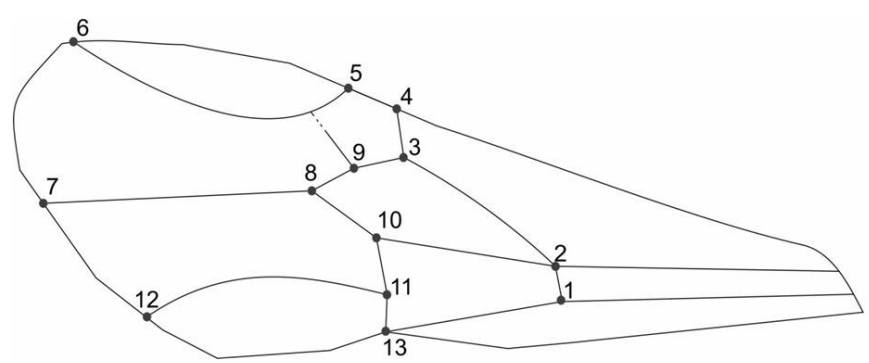

Fig 1. Left forewing showing the anatomical landmarks used in morphometric analysis.
An analysis of cross-validation between the scores of principal components and canonical variables was performed with $\mathrm{R}$ statistical software which verified the correlation of the individuals with their respective nests.

The distance matrix of Procrustes were used for the cluster analysis by UPGMA method that resulted in arrangement of wing distances between the colonies. Values of the coefficient of cophenetic correlation equal to or greater than 0.7 , using the NTSYSpc software (Rohlf, 2000) were considered for analysis.

\section{Molecular Analysis}

Extraction of DNA was performed as described by Waldschmidt et al. (1997). Adult workers preserved in 70\% ethanol and stored at $-20^{\circ} \mathrm{C}$ were used. DNA was precipitated with ethanol and resuspended in $25 \mu \mathrm{TTE}$ and stored at -20 ${ }^{\circ} \mathrm{C}$. Quality of the DNA extraction was checked by agarose gel electrophoresis and DNA was quantified using Qubit ${ }^{\circledR}$. 2.0 Fluorometer (Invitrogen).

ISSR markers and cytochrome $\mathrm{b}$ gene sequences (cyt bsequences) were used to study the genetic variability. The DNA extracted was amplified using the following ISSR primers: $(\mathrm{CA})_{8} \mathrm{RY}, \quad(\mathrm{GA})_{8} \mathrm{RY}, \mathrm{CA}_{8} \mathrm{G} \quad(\mathrm{TG})_{7} \mathrm{RG}$, (GATA) ${ }_{2}(\mathrm{CAGA})_{2}$, UBC 807, UBC 808, UBC 811, UBC 834: R UBC 836, UBC 848, UBC 856 and UBC 857 (Zietkiewicz et al., 1994; Diniz et al., 2004, 2005; Chen et al., 2005; Nascimento et al., 2010). For amplification and sequencing of the cyt $\mathrm{b}$ region, universal primers, 5'-Cyt $\mathrm{b}$ TATGTACTACC-ATGAGGACAAATATC-3 '(forward) and 5'-ATTACACCTCCTAATTTATTAGGAAT - 3' (reverse) (Crozier et al., 1991), were utilized.

PCR was in a final volume of $20 \mu \mathrm{l}$ using $10 \mu \mathrm{l}$ ofTaq Master Mix RED (Amplicon $\left.{ }^{\circledR}\right), 2 \mu 1$ of $10 \mu \mathrm{M}$ each primer, and $1 \mu \mathrm{l}$ of extracted DNA with an approximate concentration of $35 \mathrm{ng} / \mu \mathrm{l}$ using the following conditions: hold at $94^{\circ} \mathrm{C}$ for 5 min and 40 cycles of $94{ }^{\circ} \mathrm{C}$ for $30 \mathrm{sec}$, varied annealing temperature according to the melting temperature of each primer as described in Table 2, extension at $74{ }^{\circ} \mathrm{C}$ for $45 \mathrm{sec}$ and a final extention at $74{ }^{\circ} \mathrm{C}$ for $10 \mathrm{~min}$. Electrophoresis was performed using $0.8 \%$ agarose gel, stained with SYBR Green (SYBR Green I, Biotecnologia LCG) and visualized under UV.(OBS: these amplification conditions were used both ISSR and paracytb?)

PCR amplified cyt $b$ fragments were purified using Nucleo Spin ${ }^{\circledR}$ Gel and PCR Clean-up kit (Macherey-Nagel, Germany), quantified and sequenced. For sequencing, the Big Dye Terminator v.3.1 Cycle @ Sequency kit was used in the ABI 3500 sequencer (Applied Biosystems).

Analysis of the results obtained by ISSR primers were carried out using multivariate statistics. The PAST 3.4 software (Hammer et al., 2001) was used to evaluate the genetic diversity index measured by the Jaccard. Values obtained from the measurement of genetic distance were used for UPGMA cluster analysis (unweighted pair-group Method with Arithmetic Mean) and AMOVA (Analysis of 
Table 2- Primers utilized in this study for the analysis of genetic variability.

\begin{tabular}{|c|c|c|c|}
\hline Designation & Sequences of primers $\left(5^{\prime \prime}-3^{\prime \prime}\right)$ & $\mathrm{Tm}$ & reference \\
\hline (CA)8RY & CACACACACACACACARY & $56^{\circ} \mathrm{C}$ & Zietikiewicz et al, 1994 \\
\hline (GA)8RY & GAGAGAGAGAGAGAGARY & $56^{\circ} \mathrm{C}$ & Zietikiewicz et al,1994 \\
\hline (CA)8G & CACACACACACACACAG & $56^{\circ} \mathrm{C}$ & Chen et al , 2005 \\
\hline (TG)7RC & TGTGTGTGTGTGTGRC & $56 \circ \mathrm{C}$ & Zietikiewicz et al, 1994 \\
\hline$($ GATA) $2($ GACA $) 2$ & GATAGATAGACAGACA & $56^{\circ} \mathrm{C}$ & Diniz et al, 2004, 2005 \\
\hline UBC 807 & AGAGAGAGAGAGAGAGT & $54 \stackrel{\circ}{\circ}$ & Wang 2011 \\
\hline UBC 808 & AGAGAGAGAGAGAGAGC & $54 \stackrel{\circ}{C}$ & Wang 2011 \\
\hline UBC 811 & GAGAGAGGAGAGAGAC & $56^{\circ} \mathrm{C}$ & Nascimento et al, 2010 \\
\hline UBC 834 & AGAGAGAGAGAGAGAGYT & 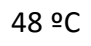 & Nascimento et al, 2010 \\
\hline UBC 836 & AGAGAGAGAGAGAGAGAGYA & $54 \stackrel{\circ}{ } \mathrm{C}$ & Nascimento et al, 2010 \\
\hline UBC 848 & CACACACACACACACARG & $56 \stackrel{\circ}{C}$ & Nascimento et al, 2010 \\
\hline UBC 856 & ACACACACACACACACYA & $48 \stackrel{\circ}{C}$ & Nascimento et al, 2010 \\
\hline UBC 857 & ACACACACACACACACYG & $50 \cong \mathrm{C}$ & Nascimento et al, 2010 \\
\hline Cytb & $\begin{array}{l}\text { F: TATGTACTACCATGAGGACAAATATC } \\
\text { R: ATTACACCTCCTAATTTATTAGGAAT' }\end{array}$ & $54^{\circ} \mathrm{C}$ & Crozier et al, 1991 \\
\hline
\end{tabular}

Molecular Variance). Using Alerquim version 3.5, Fst index was calculated and the values obtained were used to estimate the genetic distance between the populations (Excoffier et al., 2005). In addition, the software Structure v.0.6.9 (Evanno et al., 2005) was used to estimate the genetic structure of populations collected from the river São Francisco and the Caatinga region.

Staden Package Version 2.0 (Staden et al., 2001) was used to verify the quality of the Cyt $b$ gene sequences. Only sequences with Phred values above 30 were considered for subsequent analysis. The cyt $\mathrm{b}$ sequences were aligned using the ClustalW algorithm embedded in the software MEGA (Molecular Evolutionary Genetics Analysis) version 6.0.(Tamura et al., 2013).

DnaSP 5.0 (Librado \& Rozas, 2009) was used to identify haplotypes and to estimate haplotype (h) diversity among and within the populations. In order to observe the relationship among the haplotypes, analysis using the Median-Joining Network (Network 4.612) was also carried out (Bandelt et al., 1999).

\section{Results and discussion}

After screening approximately 37 ha, constituting three sampling areas fromthe mouth of the river São Francisco, all the trees found with possible nesting sites for the bees of the genus Melipona were of coconut. A total of 750 trees were numbered and analyzed, all featuring hollow generated by the pests, and in majority consisting of old coconut trees with low productivity. The sampling from the South of the river São Francisco (municipality of Brejo Grande) resulted in 14 nests of stingless bees from 200 trees analysed. This is the same region where Souza et al. (2006) described the first scientific records of the occurrence of the nests of M. quadrifasciata in the coconut palms. We verified that about $7 \%$ of potential nesting sites in this area were occupied. All colonies found were quite active, with large flow of workers foraging at the entrance of the nest, with some nests having more than one entry, and in these cases only one nest per tree was considered. Considering the high level of activity of thecolonies and the existence of this population for several years, hardiness and resistance of thesebees to isolation and in breeding must be considered, a situation contrary to the literature on the Melipona bees, but in agreement with the information published by Alves et al. (2011) who had described the successful maintenance of Melipona scutellaris colonies for a decade despite severe genetic bottleneck. In the other two sampling sites, located in the Ilha da Criminosa and north of the river São Francisco, despite a greater sampling effort and screening of about 23.5 hectares, totaling 550 trees with potential nesting sites, no $M$. quadrifasciata nests were found (Fig 2).

The group of bees found at the mouth of the river São Francisco showed tergal band pattern similar to that found in subspecies M. quadrifasciata quadrifasciata. An analysis of identity for this group of bees was performed using geometric morphometrics and compared with the standard specimens of M. quadrifasciata quadrifasciata and M. quadrifasciata anthidioides. Also was utilized standared specimen of $M$. mandacaia (Smith 1863) which is the sister species of $M$. quadrifasciata (Ramírez et al., 2010) as negative control. The result of canonical variate analysis (CVA) clearly defined the group in which the population under study belongs. In Figure 3 one can easily see the separation between the three reference groups, with the group of bees collected from the river São Francisco region overlapping with the subspecies M. quadrifasciata quadrifasciata, result in agreement with the yellow continuous tergal bands observed in them. 


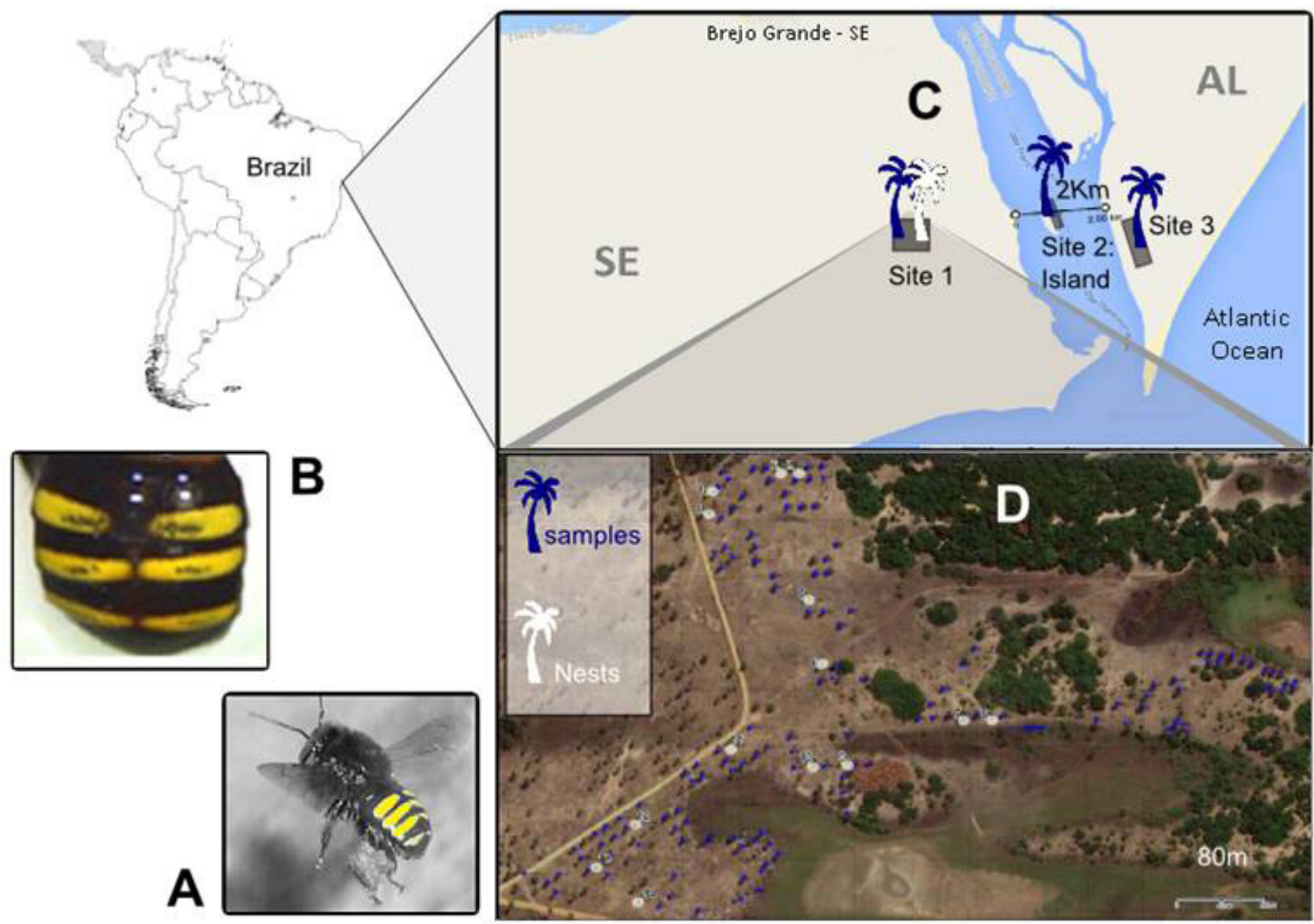

Fig 2. Sampling area and nesting sites of M. quadrifasciata in coconut groves of the river São Francisco region. A- M. quadrifasciata; B-detail of tergal bands of the collected workers; C- sampling sites: site 1 where 14 colonies of M. quadrifasciata were found, site 2: Criminosa island and site 3: left margin, state of Alagoas.

\section{Analyses of genetic diversity}

A total of 195 ISSR loci with good reproducibility were found in the two populations of $M$. quadrifasciata, collected from the river São Francisco region, and from Sergipe semiarid region. The two populations showed 143 and 119 polymorphic loci respectively and their values of the polymorphisms were $73 \%$ and $61 \%$ respectively.
Our results using ISSR demonstrated that the population of M. quadrifasciata from the mouth of the river São Francisco is significantly different from the population of M. quadrifasciata from Sergipe semiarid region. The UPGMA analysis showed a high cophenetic correlation coefficient $(\mathrm{r}=0.97)$, and together with the FST index (0.52) they confirm the genetic divergence between the two populations compared (Fig 4). Also the Bayesian algorithm implemented in STRUCTURE software

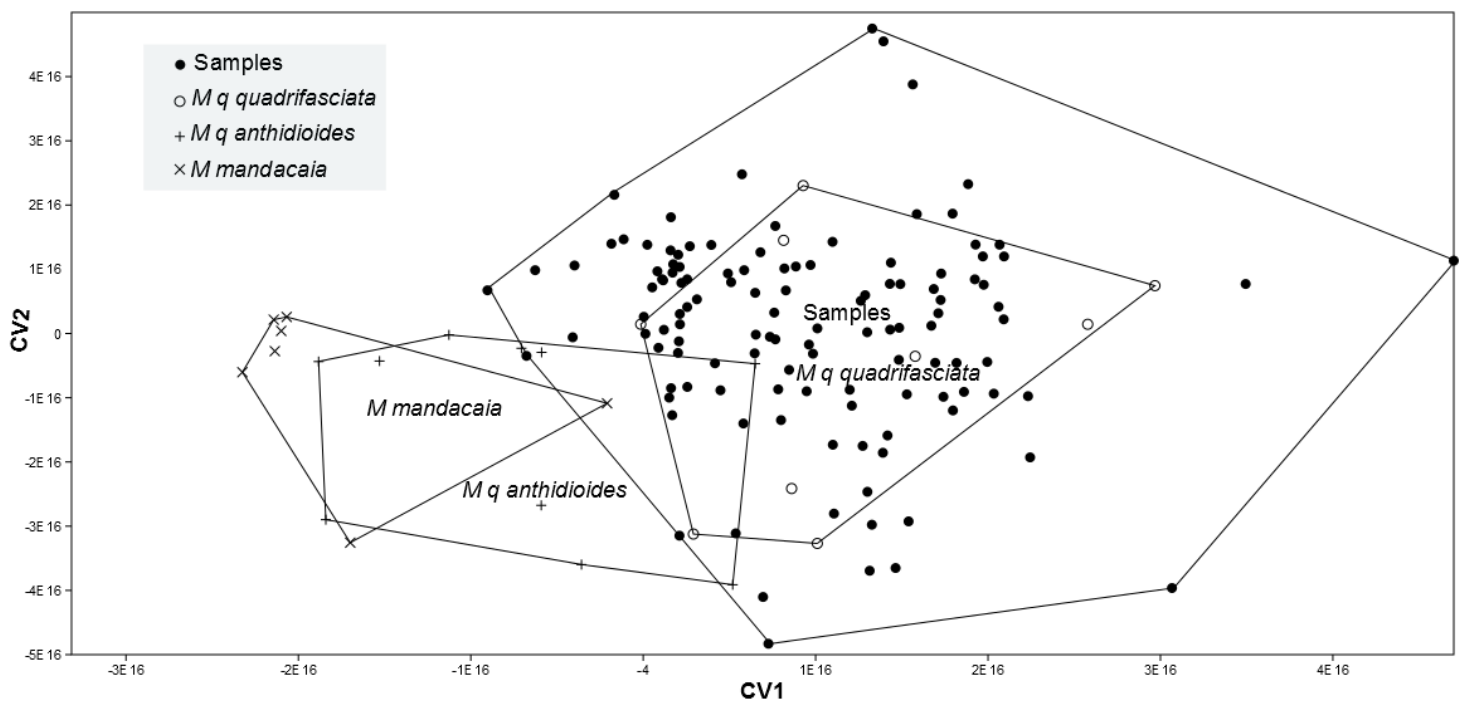

Fig 3. Analysis of the Canonical Variables showing comparison of 140 samples form 14 colonies found at the mouth of the river São Francisco with the standard specimens Melipona quadrifasciata quadrifasciata, Melipona quadrifasciata anthidioides and Melipona mandacaia. Overlapping of the samples with the standard specimen M.quadrifasciata quadrifasciata can be seen. CV1: canonical variable 1; CV2: canonical variable 2 . 




Fig 4. Dendrogram UPGMA based on ISSR markers. Cophenetic correlation index: 0.97. A: population of M. quadrifasciata from the semiarid Region (Caatinga). B: population of M. quadrifasciata found in coconut palms of the mouth of river São Francisco, coastal area of Brejo Grande, Sergipe.

using the delta $\mathrm{K}$ test (Evanno et al. 2005) showed a clear formation of two distinct clusters (Fig 5).

Analysis of molecular variance (AMOVA) provided additional support to the evidence of population differentiation between the two populations under study, with $52 \%$ and $48 \%$ of the total genetic variability distributed among and within the populations, respectively.

The comparison between cyt $\mathrm{b}$ sequences of $M$. quadrifasciata from Caatinga and Brejo Grande (South of the mouth of the river São Francisco) showed the presence of a higher genetic variability in the population of Caatinga with three distinct haplotypes, one being more frequent than the others, while in the population of Brejo Grande from the North of the river São Francisco region, only one haplotype circulating in the population was found, which is different from haplotypes circulating in the population of the Caatinga (Fig 6).

The subject of this study was a population of stingless bees found in 2006 nesting exclusively in coconut trees in a region extreme Northeast of its distribution. Despite morphological identification, no record of the presence of this species exists in the scientific literature. In this manuscript we carried out morphometric and molecular analyses of this population of stingless bees found at the mouth of the river São Francisco and confirmed that it belonged to $M$. quadrifasciata quadrifasciata. Also, all nests found at the mouth of the river San Francisco were found in the state of Sergipe, and even with greater collection effort, no nests were found North of the river. Acknowledging the fact that the confirmation of the absence of a species is more difficult than the proof of its presence, and that the absence of a finding gets stronger with higher sampling effort, we suggest that this species does not reach the state of Alagoas via the coastal region (Atlantic Forest biome) and also that the river São Francisco represents a geographic barrier strong enough for limiting the distribution of this species in the coastal region, south of the river San Francisco. Our main arguments that support this hypothesis are not based only in the sampling effort but also in the behaviour of the foundation of the new colonies and in the foraging behaviour of the stingless bees. According to Araujo et al. (2004) the flight distance in stingless bees is associated with the body size, and the size of the workers of $M$. quadrifasciata present a maximum flight

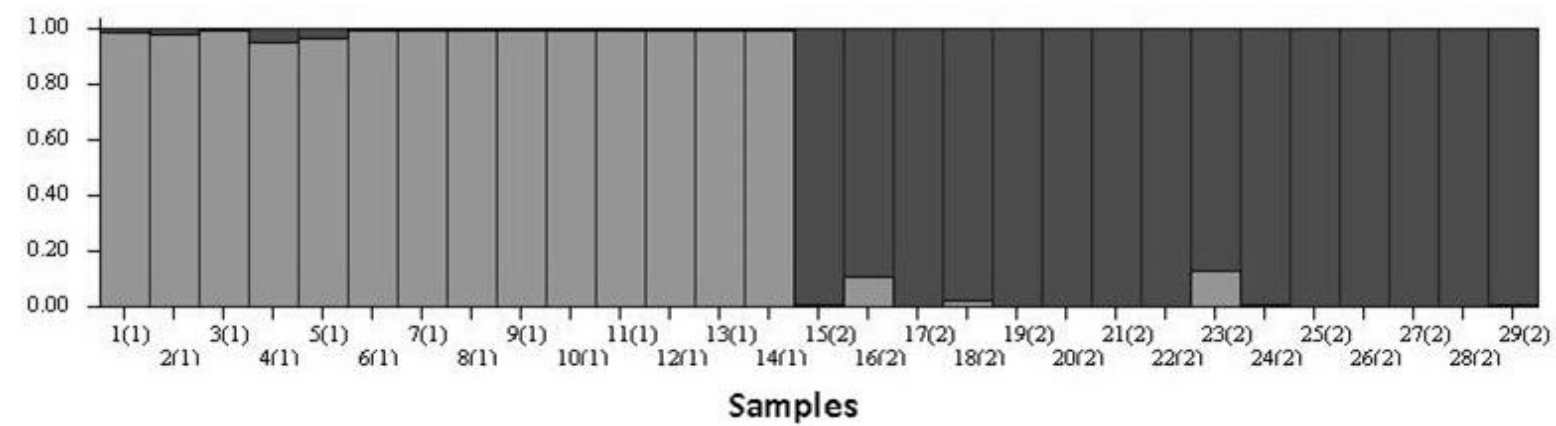

Fig 5. Population of M. quadrifasciata from the mouth of the river São Francisco (light grey) and from the semiarid region (dark grey) showing the formation of two distinct clusters using Baysian algorithm 




Fig 6. Haplotype network generated by the comparison of DNA sequences from the cytochrome b region. Population of M. quadrifasciata from semiarid Region (Caatinga) and from the mouth of river São Francisco are represented by dark grey and light grey respectively.

distance of $2 \mathrm{~km}$ radius from their colony of origin. From the standpoint of the multiplication of the colonies, restriction is even greater, since in stingless bees, reproduction and foundation of a new colony are carried out by a group of bees (queen and the workers) and generally occurs in a progressive manner, with long period of contact between the mother and the daughter colonies. This feature limits the formation of new colonies closer to the nesting site of the maternal nest (Batista et al., 2003). São Francisco is the main river in the Northeastern Brazil and the distance between its margins at the mouth, is around $2 \mathrm{~km}$ (Figure 2). Thus the river can really be considered as an effective barrier of geographic isolation for the population of this species. Following the same reasoning, the greater possibility is that the M. quadrifasciata population from the mouth of the river San Francisco region is derived from the populations of Atlantic forest biome. However, the nearest population with morphology similar to the tergal bands of the subspecies $M$. quadrifasciata quadrifasciata recorded in this region lies in the semiarid Caatinga biome in Sergipe (Batalha-Filho et al., 2009), and the bees of this species are not generally found in the coastal region of the Northeastern Brazil.

The genetic diversity found among populations analysed indicates low or absence of inter-population gene flow and / or divergent evolutionary pressures, especially considering that the populations compared belong to different biomes, although geographically separated by a linear distance of less than $150 \mathrm{Km}$. According to Araújo et al. (2000) the fixation of an allele can occur by genetic drift and depends on its initial frequency in the population. It is a process that occurs in all finite populations, and is faster in smaller populations. Thus, checking the number of haplotypes circulating in a population is essential for the genetic evaluation of the population. The sequencing analysis of the mitochondrial cytochrome $b$ region showed that the two populations have a small genetic divergence, but may belong to the same subgroup identified by the continuous tergal bands as found in the subspecies $M$. quadrifasciata quadrifasciata. However, it is noteworthy that the existence of similar tergal band patterns does not determine that this group belongs to this subspecies, and perhaps the divergence between the groups in $M$. quadrifasciata is so small that it does not even justify its separation into subspecies, as argued Batalha-Filho et al. (2009).

Our results point to some important scenarios for the local population from the mouth of the river São Francisco. First it highlights a great risk of local extinction of this species. In the genus Melipona, the species are very sensitive to the reduction in genetic variation which may increase the probability of the loss of colonies by the loss the of alleles at the Xo locus consequently producing diploid males (Carvalho et al., 1995; Araújo et al., 2000). Linked to the lack of genetic variability, the risk of extinction is also directly associated with the isolation of this population in an area where practically all the nesting sites depend on the existence of pests that damage the trunks of coconut trees. Improved cultural practices, economic subsidies or improve technical assistance to the coconut growers may result in a massive replacement of diseased coconut trees by new plants, drastically reducing the potential nesting sites and simultaneously destroying the nests of M. quadrifasciata housed in these plants.

The cytochrome $b$ sequence analysis also showed that the haplotype found in the São Francisco region is unique, and thus the loss of this population could represent a permanent loss of this genetic lineage that seems to be quite resistant to inbreeding, since all the nests encountered showed excellent level of activity despite the lack of genetic variability. Conservation actions are urgently needed, including increasing the supply of nesting sites and the development of beekeeping directed towards the multiplication of the colonies and maintenance of this haplotype in the region.

\section{Acknowledgements}

We thank the members of the association of Brejograndense de Criadores de Abelhas e Artesãos (ABECA) and FAPITEC-SE for the financial support, and CAPES and CNPq for the scholarships to the students related to this project.

\section{Conflict of Interest}

The authors declare that they have no conflict of interest. 


\section{References}

Alves D.A., Imperatriz-Fonseca V.L., Francoy T.M., SantosFilho P.S., Billen J, Wenseleers T. (2011) Successful maintenance of a stingless bee population despite a severe genetic bottleneck. Conservation Genetics, 12: 647-658. doi 10.1007/s10592-010-0171-Z

Antonini, Y., Costa, R.G., Martins, R.P. (2006). Floral preferencesof a neotropical stingless bee, Melipona quadrifasciata Lepeletier (Apidae: Meliponina) in a urban forest fragment. Revista Brasileira de Biologia, 66 (2A): 463 471. doi:10.1590/S1519-69842006000300012.

Araújo, E.D., Costa, M., Chaud-Neto, J., Fowler, H.G. (2004). Body size and flight distance in stingless bees (Hymenoptera: Meliponini): Interference of flight range and possible ecological implications. Brazilian Journal of Biology, 64: 563-368. doi: 10.1590/S1519-69842004000400003.

Araújo, E.D., Diniz-Filho, J.A.F., Oliveira, F.A. (2000). Extinção de populações locais do gênero Melipona (Hymenoptera: Meliponinae): efeito do tamanho populacional e da produção de machos por operárias. Naturalia, 25: 287-299.

Araújo, W.L., Oliveira, A.G., Ferreira, A.P.N., Sousa; Anderson Bruno Anacleto de Andrade (2015). Pest management in disease control in vegetable growing, Revolução Verde, 10: 43-50. doi: 10.18378/rvads.v10i5.3887.

Batalha-Filho, H., Melo, G.A.R., Waldschmidt, A.M., Campos, L.A.O., Fernandes-Salomão, T.M. (2009). Geographic distribution and spatial differentiation in the color pattern of abdominal stripes of the Neotropical stingless bee Melipona quadrifasciata (Hymenoptera, Apidae). Zoologia, 26: 13219. doi:10.1590/S1984-46702009000200003.

Batista, M.A., Ramalho, M., Soares, E.E.A. (2003).Nesting sites and abundance of Meliponini (Hymenoptera: Apidae) in heterogeneous habitats of the Atlantic Rain Forest, Bahia, Brazil. Lundiana, 4: 19-23.

Bandelt, H.J., Forster, P., Rohl, A. (1999). Median-joining networks for inferring intraspecific phylogenies. Molecular Biology and Evolution, 16: 37-48

Beaumont, M.A., Bruford, M.W. (1999). Microssatelites in conservation genetics. InD.B. Goldstein \& C. schotterer (Eds.), Microssatelites: Evolution and Aplications (pp.165-182). New York: Oxford University Press.

Camargo, J.M.F., Pedro, S.M.R. (2007). Meliponini Lepelitier, 1836 pp272-578. In: JS Moure, DUR Bane GAR Melo (EDs) Catalogue off bee (Hymenoptera, Apoidae) in the Neotropical Region Curitiba. Revista Brasileira de Zoologia, 21: 1558. doi:10.1590/s0101-81752002000500001.

Carvalho, G.A., Kerr, W., Nascimento, V.A. (1995). Sex determination in bees. XXXVII. Decrease of Xo hetero alleles in a finite population of Melipona scutellaris. (Apidae, Meliponini). Revista Brasileira de Genética, 18: 13-16.
Chakrabortyr, R., Kimmel, M. (1999). Statistics of microssatélites loci: estimation of mutation rate and pattern of population expansion. In D.B. Goldstein \& C. schotterer (Eds.), Microssatélites: Evolution and applications (pp.139150). New York: Oxford University Press.

Chen, K., Kinorr, C., Bornemann-Kolatzki, K., Ren, J., Huang, L., Rohrer, G.A., Brenig, B. (2005). Targeted oligonucleotidemediated microsatellite identificatio (TOMMI) from largeinsert library clones. BMC Genetics, 6: 54. doi:10.1186/14712156-6-54.

Crozier, Y.C., Koulianos, S., Crozier, R.H. (1991). An improved test for Africanized honey bee mitochondrial DNA. Experientia, 47: 968-969. doi:10.1007/BF01929894.

Cuenca, M.A.G., Nazario, C.C. (2004). Evolução da cocoicultura no Estado e nos tabuleiros costeiros do Rio Grande do Norte no período de 1990 a 2002. Aracaju: Embrapa Tabuleiros Costeiros, 26p

Diniz, F.M., Maclean, N., Paterson, I.G., Bentzen, P. (2004). Polymorphic tetranucleotide microsatellite markers in the Caribbean spiny lobster, Panulirusargus. Molecular Ecology Notes, 4: 327-329. doi:10.1111/j.1471-8286.2004.00683.x.

Diniz, F.M., Maclean, N., Ogawa, M., Paterson, I.G., Bentzen, P. (2005). Microsatellites in the overexploited spiny lobster, Panulirusargus: Isolation, characterization of loci and potential for intraspecific variability studies. Conservation Genetics, 6: 637-641. doi:10.1007/s10592-005-9018-4.

Evanno, G., Regnaut, S., Goudet, J. (2005). Detecting the number of clusters of individuals using the software STRUCTURE: a simulation study. Molecular Ecology, 14: 2611-2620

Excoffier, L., Laval, G., Schneider, S. (2005). Arlequin ver. 3.0: an integrated software package for population genetics data analysis. Evolutionary Bioinformatics, 1: 47-50.

Hammer, O., Harper, D.A.T., Ryan, P.D. (2001). Past: Paleontological Statistics Software Package for Education and Data Analysis. Paleontological Electronica, 4: 1-9.

Kerr, W.E., Vencovsky, R.(1982). Melhoramento genético em abelhas I. Efeito do número de colônias sobre o melhoramento. Revista Brasileira de Genética, 5: 279-285.

Kerr, E.W., Carvalho, G.A., Nascimento, V.A. (1996). Abelha uruçu: Biologia, Manejo e Conservação. Belo Horizonte: Acangaú, 154p

Klingenberg, P.C. (2010).Morphoj: an integrated software package for geometric Morphometrics. Molecular Ecology Resources, 11: 353-357. doi:10.1111/j.1755-0998.2010.02924.x.

Librado, P., Rozas, J. (2009). DnaSP v5: A software for comprehensive analysis of DNA polymorphism data. Bioinformatics, 25: 1451-1452. doi:10.1093/bioinformatics/btp187.

Moritz, C.,\& Hills, D.M. (1996). Molecular systematics: context and controversies. InD.M. Hills; C. Moritz \& B.K. 
Mable (eds.), Molecular systematics (pp.1-13), Sunderland: Sinauer Associates.

Nascimento, M.A., Batalha-Filho, H., Waldschmidt, A.M., Tavares, M.G., Campos, L.A.O., Fernandes-Salomão, T.M. (2010). Variation and genetic structure of Melipona quadrifasciata Lepeletier. Genetics and Molecular Biology, 33: 394-397. doi:10.1590/S1415-47572010005000052.

Ramalho, M. (2004). Stingless bees and mass flowering trees in the canopy of Atlantic Forest: a tight relationship. Acta Botanica Brasílica, 18: 37-47. doi:10.1590/S0102-33062004000100005.

Ramírez S.R., Nieh J.C., Quental T.B., Roubik D.W., ImperatrizFonseca V.L., Pierce N.E. (2010). A molecular phylogeny of the stingless bee genus Melipona (Hymwenoptera: Apidae). Molecular Phylogenetics and Evolution, 56: 519-525.

Ribeiro, M.C., Metzger, J. P., Martensen, A.M., Ponzoni, F.J., Hirota, M.M.(2009). The Brazilian Atlantic Forest: How much is left, and how is the remaining forest distributed: Implications for conservation. Biological Conservation, 142: 11411153. doi:10.1007/978-3-642-20992-5_21.

Rolfh, F.J. (2000). NTSYS-pc: numerical taxonomy and multivariate analysis system, version 2.1. Exeter Software: State University of New York, Setauket.

Rolfh, F.J. (2006) tpsDIG, Version 2.10. Department of Ecology and Evolution, State University of New York, Stony Brook.

Silveira, F.A., Melo, G.A.R., Almeida, E.A.B. (2002). Abelhas brasileiras: sistemática e identificação. Belo Horizonte: Fundação Araucária.

Siqueira, L.A.; Aragão, W.M.; Tupinambá, E.A. A introdução do coqueiro no Brasil: importância histórica e agronômica. Aracaju: Embrapa Tabuleiros Costeiros, 2002. 24p.

Staden, R., JudgeD.P., Bonfield, J.K. (2001). Sequence assembly and finishing methods. Methods of Biochemical Analysis, 43: 303-322.

Souza, B.A., Carvalho, C.A., Alvez, M.O., Dias, C.S. (2009). Munduri: (Meliponaasilvae) a abelha sestrosa. Cruz das Almas: Grupo Insecta - UFRB.
Souza, C.B., Santos, D.M., Araújo, E.D. (2006). Nidificação de Mandaçaia (Melipona quadrifasciata quadrifasciata) em coqueirais da região da foz do rio São Francisco. Aracaju: Anais do XVI Congressso Brasileiro de Apicultura.

Tamura, K.,Stecher G., Peterson D., Filipski A., Kumar S. (2013). MEGA6: Molecular Evolutionary Genetics Analysis (MEGA) software versão6.0. Molecular Biology and Evolution, 30(12):2725-2729. doi.10.1093/molbev/mst19.

Tavares, M.G., Pietrani, N.T., Durvale, M.C., Resende, H.C., Campos, L.A.O. (2013) Genetic divergence between Melipona quadrifasciata Lepeletier (Hymenoptera, Apidae) populations. Genetics and Molecular Biology, 36: 111-117. doi.10.1590/ s1415-47572007000400027.

Waldschmidt, A.M., Marco-Júnior, P., Barros, E.G., Campos, L.A.O.(2002).Genetic Alalysis of Melipona quadrifasciata Lep. (Hymenoptera: Apidae, Meliponinae) With RAPD Markers. Brazilian Journal of Biology, 62: 923-928.

Waldschmidt, A.M., Barros, E.G., Campos, L.A.O. (2000). A molecular marker distinguishes the subspecies Melipona quadrifasciata quadrifasciata and Melipona quadrifasciata anthidioides (Hymenoptera, Apidae, Meliponinae). Genetics and Molecular Biology, 23: 609-611. doi:10.1590/S1415-475 72000000300019 .

Waldschmidt, A.M., Salomão, T.M.F., Barros, E.G., Campos, L.A.O. (1997). Methodology: Extration of genomic de DNA from Melipona quadrifasciata (Hymenoptera: Apidae, Meliponinae). Brazilian Journal of Biology, 20: 421-423. doi:10.1590/S010084551997000300011.

Wang, Xu Mei (2011). Inter-Simple sequence repearts (ISSR) molecular fingerprinting markers for authenticating the genuine species of rhubard. Journal of Medicinal Plants Research, 5: 758-764.

Zietkiewicz, E., Ralfski, A.,Labuda, D. (1994). Genome Frigerprinting by simple sequence (SSR) - Anchored Polymerase Chain Reaction Amplification. Genomics, 20: 176-183. doi:10. 1006/geno.1994.1151. 